\title{
Dramat ludzkiego ja (Rz 7, 14-25)
}

Rz 7, 14-25 stanowi drugą część bloku tematycznego obejmującego 7, 7-25, który traktuje o Prawie i przykazaniu. Mimo iż są one święte i dobre, to jednak nie potrafią wyzwolić ludzkiego ja z mocy grzechu. Pierwsza część wspomnianego bloku 7, 7-13 podejmuje relację między Prawem a grzechem. Podkreśla, że grzech jest wcześniejszy względem Prawa, stanowi także jego skutek ${ }^{1}$. Natomiast 7, 14-25 ukazuje dramat ludzkiego ja. Uznaje ono dobroć Prawa i jednocześnie nie jest zdolne, by nim żyć. W omawianej perykopie możemy wyróżnić dwie jednostki:

-ww. 14-20 przedstawiają rozbicie między chcieć a czynić w odniesieniu do ja,

- ww. 21-25 wyrażają bezradność ja oraz Prawa².

Nadto wersety 14-17 oraz 18-20 wzajemnie sobie odpowiadają. Tworzą retoryczną commoratio, czyli powtórzenie tej samej tematyki różnymi słowami. Należy jednak zaznaczyć, iż w ww. 14-17 ja jest umieszczone w relacji do Prawa, zaś w ww. 18-20 akcent pada na ja wewnętrzne, zamieszkane lub opanowane przez zło grzechu ${ }^{3}$.

Rz 7, 14-25 charakteryzuje styl właściwy diatrybie ${ }^{4}$, jest on bardzo żywy. Zawiera pytanie retoryczne i natychmiastową odpowiedź (w. 24). Dostrzegamy w nim również personifikację grzechu („czyni” - w. 17; „mieszka” -w. 20) oraz Prawa („toczy walkę” - w. 23). Ja występujące w Rz 7, 14-25 należy uznać jako retoryczne, czyli wyrażające sposób odniesienia się do każdego człowieka będącego poza Chrystusem. Jeśli w miejsce ja umieścilibyśmy ty lub my - sytuacja nie uległaby zmianie ${ }^{5}$.

${ }^{1}$ Por. R. Penna, Lettera ai Romani (II. Rm 6-11), Bologna 2006, s. 83.

${ }^{2}$ R. Penna dzieli perykopę na dwie części obejmujące wersety 14-23 - nieskuteczność Prawa wobec osobistego doświadczenia grzechu oraz 24-25 - epilog. Nadto w wersetach 14-23 wyodrębnia trzy jednostki oparte na znajomości rzeczy: ww. 14-17 - oło $\alpha \mu \in \nu$ (,wiemy”); ww. 18-

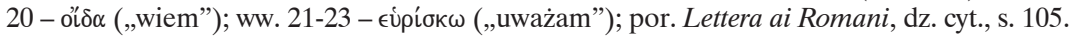

${ }^{3}$ Por. tamże, s. 267.

${ }^{4}$ Por. A. Pitta, Lettera ai Romani, Milano 20012, s. 62.

${ }^{5}$ Por. tamże. W pierwotnym Kościele ja odnoszono do Adama, który przekroczył 


\section{Rozbicie między chcieć a czynić w odniesieniu do ja}

Paweł, posługując się pierwszą osobą liczby mnogiej „wiemy”, pragnie skierować uwagę czytelnika ku przekazanym treściom6. Stwierdza, iż Prawo jest duchowe - $\pi \nu \in \cup \mu \alpha \tau \iota \kappa o ́ s$, czyli nie należy do rzeczywistości związanych z ziemią, lecz do sfery Ducha Bożego ${ }^{7}$. W judaizmie uważano, że Tora ma niebiańskie źródło. Nigdzie jednak nie spotyka się stwierdzenia, iż jest duchowa ${ }^{8}$.

Prawo nie może zatem być rozumiane jedynie jako $\gamma \rho \alpha \dot{\mu} \mu \mu \alpha$ („litera”), która przeciwstawia się Duchowi (por. Rz 2, 29; 7, 6), ponieważ wyraża także wolę Bożąa . Paweł podkreśla więc wartość Prawa (por. Rz 7, 12), jednak cały akcent w wersecie 14 spoczywa na podwójnym stwierdzeniu dotyczącym ludzkiej kondycji. Charakteryzuje ją cielesność oraz niewola

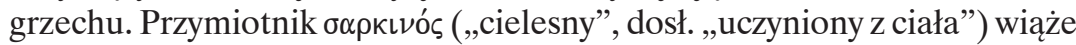
się z ciałem ó́ $\rho \xi^{10}$, które nie jest ukierunkowane ku Bogu, lecz zwrócone ku ziemi ${ }^{11}$. Ciało oznacza człowieka w jego słabości i podatności na zło ${ }^{12}$. To samo przekonanie odnajdujemy także w jednej z modlitw z Qumran: „Należę do niegodziwej ludzkości, do tłumu niecnie postępującego cia-

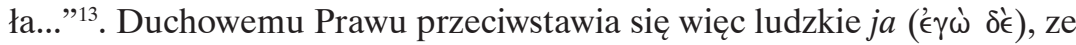

Boże przykazanie i sprawił, że moc grzechu wtargnęła w ten świat. Uważano również, że Adam nie jest tylko pojedynczą osobą, w ja można bowiem rozpoznać lud Tory. Augustyn najpierw reprezentował pogląd, że tekst Rz 7 mówi o nieodkupionym człowieku. W sporze z Pelagiuszem zmienił swe zdanie i odniósł ja do Pawła - chrześcijanina; por. E. LoHSE, Der Brief an die Römer, $2003^{15}$, s. 213-214.

${ }^{6}$ Por. D. J. Moo, The Epistle to the Romans, Grand Rapids 1996, s. 453.

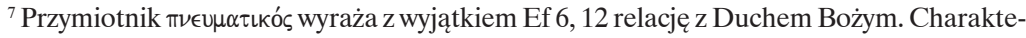
ryzuje istoty należące do porządku nadprzyrodzonego (por. 1 Kor 15, 44); por. S. RomanELLo, Una legge buona ma impotente, Bologna 2000, s. 137.

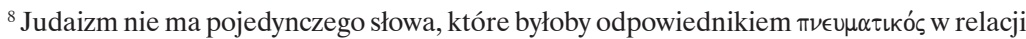
do Tory. Rabini zwracali natomiast uwagę, iż Tora ma boskie pochodzenie. Między innymi twierdzili: „Kto mówi [...]: Tora nie pochodzi od Boga, zalicza się do tych, co nie będą mieli udziału w przyszłym życiu"; por. H. L. Strack, P. BiLlerbeck, Kommentar zum Neuen Testament aus Talmud und Midrasch, München 1954, t. 3, s. 238.

${ }^{9}$ Por. J. A. Fitzmyer, Lettera ai Romani, Casale Monferrato 1999, s. 563-564.

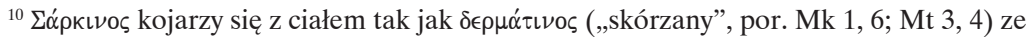
skórą; por. H. Schlier, Der Römerbrief, Freiburg-Basel-Wien 20024, s. 229. Przyrostek -ıvo wskazuje na materię, rodzaj, gatunek; por. F. Blass, A. Debrunner, F. ReHKoPf, Grammatik des neutestamentlichen Griechisch, Göttingen $1984^{16}$, par. 113.

${ }^{11}$ Por. J. A. Fitzmyer, Lettera ai Romani, dz. cyt., s. 564.

${ }^{12}$ Por. G. RAfiński, Grzech ludzkości i dar usprawiedliwienia. List św. Pawła do Rzymian, [w:] Dzieje Apostolskie. Listy św. Pawła, Warszawa 1997, s. 339 (Wprowadzenie w Myśl i Wezwanie Ksiąg Biblijnych, 9).

${ }^{13}$ E. LoHSE, Der Brief an die Römer, dz. cyt., s. 220. Autor powołuje się na 1 QS XI, 9. 12. 
względu na swą cielesną, ziemską naturę odziedziczoną po Adamie ${ }^{14}$. Jest ono w niewoli grzechu. Czasownik $\pi\llcorner\pi \rho \alpha ́ \sigma \kappa \in \iota \nu$ („sprzedawać”) często odnosi się w LXX do sprzedaży ludzi (por. Rdz 31, 15; Wj 22, 2; Kpł 25, 39. 42. 47n; Pwt 15, 12) i oddaje ideę niewoli (por. Mt 18, 25). W piśmiennictwie Pawłowym pojawia się tylko raz, właśnie w omawianym wersecie 14. Również tutaj w znaczeniu przenośnym nawiązuje do niewolnictwa ${ }^{15}$. Opisuje człowieka, który stracił swą niezależność, popadł w moc grzechu i znalazł się w sytuacji, z której może go wybawić jedynie Bóg ${ }^{16}$. Stan jego niewoli jest trwały, a zaistniał już w przeszłości (por. Rz 5, 12-21), jak to potwierdza

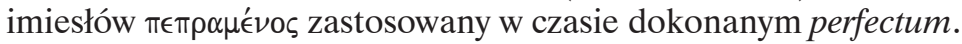

Grzech zagarnia wnętrze człowieka i wywiera na niego swój zgubny wpływ widoczny w zewnętrznym postępowaniu (w. 15). Czasowniki

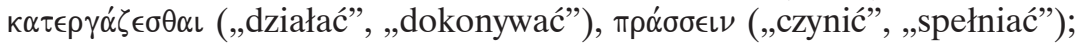
molê̂v („czynić”, „robić”) są synonimami stosowanymi dla odmiany stylu ${ }^{17}$. Opisują zewnętrznie dostrzegalne działanie. Ludzkie ja jednak go nie rozumie i nie ma nad nim władzy. W człowieku zniewolonym przez grzech panuje więc rozdarcie, pęknięcie. Ja znajduje się w ekstremalnym konflikcie. Wprawdzie wie, jak powinno się postępować, jednak działa inaczej ${ }^{18}$. Prawo, chociaż jest duchowe, nie może wpłynąć na jego działanie ${ }^{19}$.

Esseńczycy z Qumran tłumaczyli ten wewnętrzny dramat, uważając, że Bóg umieścił w człowieku dwa duchy, by nim kierowały aż do czasu Jego nawiedzenia. Jeden z nich jest duchem prawdy, drugi zaś duchem perwersji. Są one w nieustannej walce ${ }^{20}$. Paweł-jak zauważyliśmy - inaczej interpretuje wewnętrzne rozszczepienie ludzkiego wnętrza. Nie przypisuje go Bogu czy duchom, lecz samemu człowiekowi i grzechowi, który w nim mieszka.

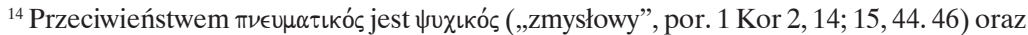

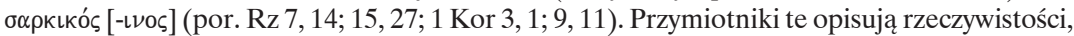
które nie odnoszą się do Ducha i łaski. Gdy zachodzący między nimi kontrast ma wydźwięk

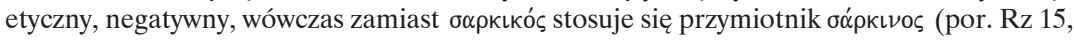
27; 1 Kor 9, 11); por. S. Romanello, Una legge buona ma impotente, dz. cyt., s. 137.

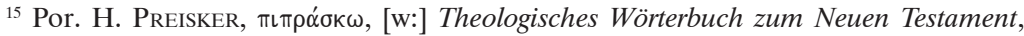
begründet von G. Kittel in Verbindung mit zahlreichen Fachgenossen, hrsg. von G. Friedrich, t. 6, Stuttgart [1959], s. 161.

${ }^{16}$ Por. tamże.

${ }^{17}$ Por. A. Pitta, Lettera ai Romani, dz. cyt., s. 276; por. także S. Romanello, Una legge buona ma impotente, dz. cyt., 141.

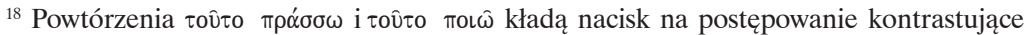

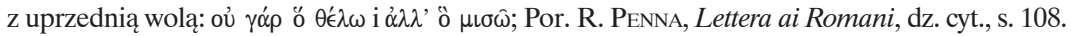

${ }^{19}$ Por. S. Romanello, Una legge buona ma impotente, dz. cyt., 140.

${ }^{20}$ Por. J. A. Fitzmyer, Lettera ai Romani, dz. cyt., s. 565. Autor powołuje się na 1 QD 3, 14- 4, 26; por. także D. Zeller, Der Brief an die Römer, Regensburg 1984³ , s. 143. Autor przytacza 1 QS IV, 23. 
Sytuacja ludzkiego ja jest paralelna do $\mathrm{Medei}^{21} \mathrm{w}$ tragedii Eurypidesa Medea napisanej w 431 roku przed Chrystusem. Dzieło to dało początek w literaturze grecko-rzymskiej motywowi niemocy, bezsilności - $\alpha \kappa \rho \alpha \sigma i \alpha$. W szczytowej fazie swego konfliktu, tuż przed zabiciem własnych dzieci Medea krzyczy: „Zdaję sobie sprawę [dosł. rozumiem] ze zbrodni, którą mam dokonać, lecz żądza <zemsty>, która jest przyczyną największych nieszczęść dla śmiertelników, okazuje się mocniejsza od mych postanowień"22.

Paweł nie waha się podjąć tego motywu w kontekście chrześcijańskim.

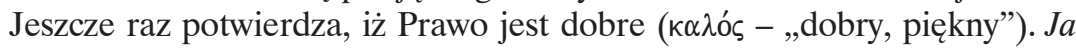
chciałoby je wypełniać, jednak jego wola okazuje się bezsilna (w. 16). Obezwładnia ją grzech, który sięga aż do wnętrza ja i zachowuje się jak pan jego domu na stałe w nim zamieszkujący (ołkoûб $\alpha-$ w. 17). W tym dramacie ja staje się jedynie widzem, nie posiada władzy nad sobą, traci swoją autonomię ${ }^{23}$. Wydaje się, że obecność grzechu w ja znajdującym się poza Chrystusem jest okolicznością łagodzącą odpowiedzialność moralną człowieka. W rzeczywistości akcent pada nie na usprawiedliwienie podmiotu ludzkiego, lecz raczej na realizm konfliktu, opozycję między chceniem a działaniem² ${ }^{24}$.

Opisana przez Pawła bezsilność ludzka znacząco odbiega od ponurej wizji człowieka w tekstach z Qumran. Brak w nich konfrontacji między słabością woli wobec wymagań Prawa a mocą grzechu, który niweczy szlachetne postanowienia ${ }^{25}$. Człowiek jest tam widziany jako źródło nieczystości, piec niegodziwości, duch błędu i deprawacji ${ }^{26}$.

${ }^{21}$ Medea była mityczną córką króla Ajetasa. Jej imię oznacza przebiegła. Gdy się dowiedziała, że jej mąż Jazon (mityczny heros z Tesalii) zamierza ją porzucić, by poślubić Glaukę, córkę króla Koryntu, Medea wpadła szał. Posłała jej szatę i diadem nasączone trucizną. Spowodowało to śmierć Glauki i jej ojca. Następnie zasztyletowała dwoje dzieci, jakie miała z Jazonem i schroniła się u króla Aten; por. D. SACKs, Medea, [w:] Encyklopedia świata starożytnych Greków, Warszawa 2001, s. 249; por. także R.V. HugGins, Alleged classical parallels to Paul's ,What I want to do I do not do, but what I hate, that I do” (Rom 7: 15), „Wesminster Theological Journal" 54 (1992), s. 157.

${ }^{22}$ Por. A. PitTA, Lettera ai Romani, dz. cyt., s. 277. Autor przytacza tragedię Eurypidesa: Medea 1078-1080. W epoce hellenistycznej nawiązują do niej Epiktet, Seneka i Owidiusz i podkreślają dramat między dobrem a ludzką niezdolnością, by je pełnić; por. tamże. Autor powołuje się na: EPIKTET, Dissertationes 2, 26, 4: „Nie czyni tego, co chce, natomiast czyni to, czego nie chce” - przyp. 302; SENEKA, Fedra 600: „Wy wszyscy niebianie jesteście świadkami, że nie chcę tego, co chcę” - przyp. 303; Owidiusz, Metamorphoseon 7, 17, 20-21: „Widzę to, co jest lepsze i aprobuję, lecz idę za tym, co gorsze" - przyp. 304.

${ }^{23}$ Por. H. LangKammer, List do Rzymian, Lublin 1999, s. 97 (Pismo Święte Nowego Testamentu, 6.1).

${ }^{24}$ Por. R. Penna, Lettera ai Romani, dz. cyt., s. 111.

${ }^{25}$ Por. tamże.

${ }^{26}$ Por. tamże. Autor powołuje się na 1 QH 9/1, 21-22. 
Wersety 18-19 stanowią przedłużenie fundamentalnej sekcji 7, 14-17. Krążą wokół tej samej tematyki. Ukazują nie do uzdrowienia kontrast między chcieć i nie czynić lub nie chcieć i czynić. Znaczenie tych wersetów jest również uniwersalne, jak ww. 14-17. Przedstawiają dramat każdego człowieka będącego poza Chrystusem. Paweł nie podziela optymizmu stoików, którzy uważali, że wystarczy chcieć dobra, aby być dobrym ${ }^{27}$. Apostoł wie doskonale, iż w człowieku kryje się bezsilność, która paraliżuje jego wolę na poziomie decyzji.

Wzmianka o ciele ( $\sigma \alpha \alpha \rho \xi-$ w. 18) przypomina, iż człowiek jest stworzeniem, grzech przejął nad nim kontrolę i determinuje jego działania ${ }^{28}$. Upadek człowieka nie jest jednak całkowity, skoro posiada jeszcze zdrowe chcenie ${ }^{29}$. Należy zaznaczyć, iż Paweł stosuje dwa klasyczne przymiotniki w znaczeniu

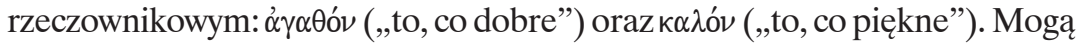

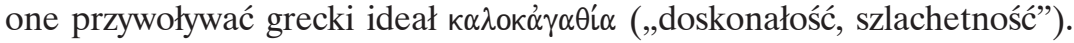
Syntetyzuje on to, co piękne i dobre ${ }^{30}$. Dla Pawła człowiek określony mianem

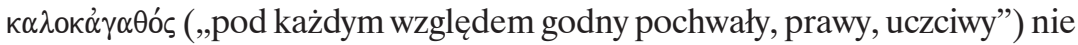
istnieje albo jest poddany mocnym ograniczeniom moralnym ${ }^{31}$. Skutki jego działania mimo dobrych pragnień okażą się złe. Czynienie przez ja tego, czego nie chce (w. 19), nie jest apologią człowieka i oskarżeniem grzechu ${ }^{32}$. Paweł nie uwalnia człowieka z moralnej odpowiedzialności ${ }^{33}$. Grzech zamieszkujący ja nie jest oddzielony od grzechu, który to samo ja popełnia ${ }^{34}$. Zawsze pozostaje więc grzechem człowieka (por. Rz 5, 12).

\section{Bezradność ludzkiego ,ja” oraz Prawa (ww. 21-25)}

W drugiej części perykopy Paweł podejmuje wyraźnie temat Prawa

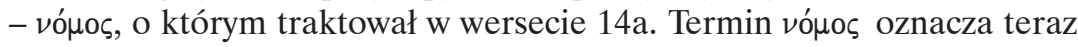
więcej niż jedną rzeczywistośćc ${ }^{35}$. Nadto czasowniki w ww. 21-25 występują

${ }^{27}$ Por. tamże, 112. Autor przytacza słowa Seneki: „Quid tibi opus est ut sis bonus? Velle!” - „Czego potrzebujesz, aby być dobrym? Chciej [nim być]!” (Epistulae 80, 4).

${ }^{28}$ Por. D. J. Moo, The Epistle to the Romans, dz. cyt., s. 458.

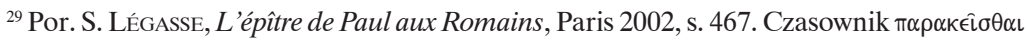
(,stać obok”, „być pod ręką”) podkreśla, iż wola ludzka jest gotowa, dyspozycyjna, aby czynić dobro. Chęć ta pozostaje jednak na poziomie pragnienia.

${ }^{30}$ Por. R. Penna, Lettera ai Romani, dz. cyt., s. 113.

${ }^{31}$ Por. tamże.

${ }^{32}$ Por. A. Pitta, Lettera ai Romani, dz. cyt., s. 279.

${ }^{33}$ Por. J. A. Fitzmyer, Lettera ai Romani, dz. cyt., s. 565.

${ }^{34}$ Por. A. Pitta, Lettera ai Romani, dz. cyt., s. 279.

${ }^{35}$ Paweł posługuje się figurą retoryczną antanaklasis, to znaczy, iż ten sam termin przyjmuje więcej znaczeń; por. S. Romanello, Una legge buona ma impotente, dz. cyt., s. 157. Nónoç w ww. 


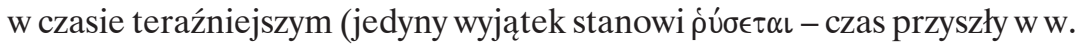
24). Zatem to, co się stwierdza w odniesieniu do ludzkiego ja, jest czymś trwałym, ma charakter kontynuacji ${ }^{36}$.

Werset 21 odsyła do tego, co już zostało powiedziane. Czasownik

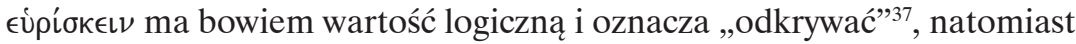
partykuła «’ $\rho \alpha$ („zatem”) ma wydźwięk konsekwencji. Jednocześnie wprowadza pojęcie vó Wewnętrzny dramat ja otrzymuje w pewien sposób ponowne wyjaśnienie. Wewnętrzną dysharmonię człowieka tłumaczy już nie grzech (ww. 17. 20), lecz prawo rozumiane tutaj jako zasada, reguła ${ }^{38}$. Otóż gdy wola jest ukie-

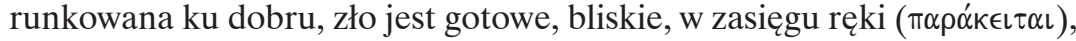
by zawładnąć całym $j a^{39}$. Zasada ta stwierdza, iż dobro jest dostępne dla ja jedynie $\mathrm{w}$ sferze idealizmu. W praktyce natomiast zostaje zwyciężone

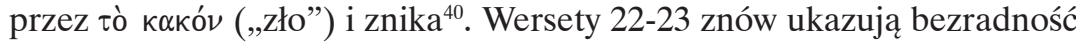
ja, które wprawdzie znajduje upodobanie w Prawie Bożym, jednak nie znajduje w sobie mocy, by iść za jego wskazaniami.

$J a \mathrm{w}$ w. 22 jest opisane jako wewnętrzny człowiek. W filozofii greckiej

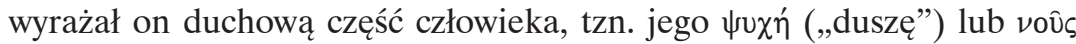
(„intelekt”). Paweł jednak nie podziela antropologii greckiej, według której osoba ludzka składa się z cielesnej powłoki okrywającej cenną duszę. Dla Pawła człowiek jest niepodzielny ${ }^{41}$. Cały tekst Rz 7, 14-25 mówi o jednym ja dramatycznie podzielonym w sobie samym; o jednym podmiocie pragnienia dobra, jak również czynienia zła. Wewnętrzny człowiek (por. 2 Kor 4, 16; Ef 3, 16) nie przeciwstawia się człowiekowi zewnętrznemu. Wskazuje jedynie na pewien aspekt ${ }^{42}$. W naszym przypadku dotyczy całego człowieka w jego wewnętrznej głębi ${ }^{43}$.

21-25 widzimy w różnych konstrukcjach: jako Prawo - w. 21; jako Prawo Boże-ww. 22. 25b; jako inne prawo - 23a; jako prawo własnego umysłu - 23b; jako prawo grzechu - w. 23c. 25c.

${ }^{36}$ Por. tamże, s. 156.

${ }^{37}$ Por. H. Schlier, Der Römerbrief, dz. cyt., s. 231.

${ }^{38}$ Por. R. Penna, Lettera ai Romani, dz. cyt., s. 115.

${ }^{39}$ Por. S. Romanello, Una legge buona ma impotente, dz. cyt., 157. W sferze działania - jak

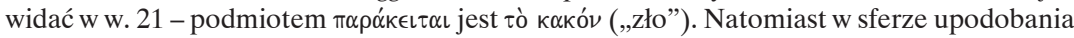

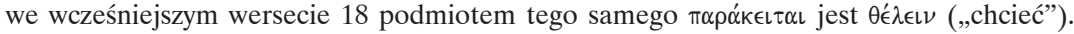
Upodobanie nie ma więc wpływu na działanie.

${ }^{40}$ Por. R. Penna, Lettera ai Romani, dz. cyt., s. 117.

${ }^{41}$ Por. S. LÉGAsse, L'épître de Paul aux Romains, dz. cyt., s. 469.

${ }^{42}$ Por. H. Schlier, Der Römerbrief, dz. cyt., s. 234.

${ }^{43}$ Por. A. PITTA, Lettera ai Romani, dz. cyt., s. 280 . W wersecie 23 pojawia się z kolei określenie $\tau \grave{\alpha} \mu^{\prime} \hat{\epsilon} \lambda \eta$ („członki”), które opisuje całego człowieka w jego działaniu. Por. H. SCHLIER, Der Römerbrief, dz. cyt., s. 233. 
Wewnętrzny człowiek raduje się w Prawie Bożym ${ }^{44}$. Po raz pierwszy w obecnej argumentacji Prawo jest określone jako boskie, czyli odnoszące się do Boga. Tego typu kwalifikacja Prawa Mojżeszowego pojawia się w Nowym Testamencie jedynie tutaj oraz w 8, 7 i stanowi szczyt pozytywnych wypowiedzi na temat Tory (por. 7, 12.14) (5) $^{45}$

Prawo, chociaż ma rodowód boski i jest święte (por. w. 12), duchowe (por. w. 14), to jednak nie wpływa pobudzająco na człowieka, aby czynił dobro. Jego przeciwieństwem jest inne prawo, które wywiera zgubny wpływ na ludzkie ja. Moc tego prawa objawia chiastyczna struktura wersetu $23^{46}$.

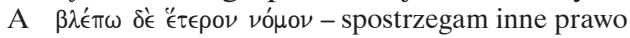

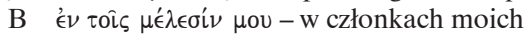

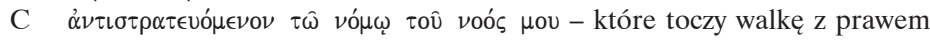
mojego umysłu

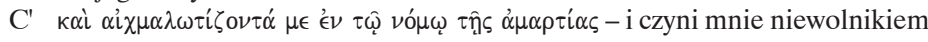
prawa grzechu

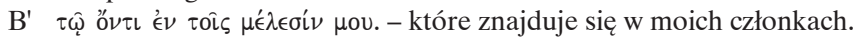

Centrum chiazmu (C-C') stanowi kontrast między prawem umysłu i prawem grzechu widoczny także w zastosowanych czasownikach: „toczyć walkę” i „czynić niewolnikiem”. B-B' podkreśla miejsce walki - moje członki. Na obrzeżu chiazmu znajduje się inne prawo. Utożsamia się ono z prawem grze$\mathrm{chu}^{47}$. Inne prawo odróżnia się od Prawa Mojżeszowego. Przymiotnik “̈ $\tau \in \rho \circ \varsigma$ określa bowiem inną rzeczywistość niż ta, o której była wcześniej mowa ${ }^{48}$.

"E $\tau \in \rho \circ \varsigma$ vónos jest zasadą niemocy ludzkiej opisaną w wersecie $21^{49}$, regułą normatywną, która rządzi człowiekiem ${ }^{50}$. Sprawia iż ja czyni zło, chociaż pragnie dobra. Werset 23 mówi także o prawie umysłu człowieka. Dla Pawła vô̂ wiąże się z wewnętrznym człowiekiem, opisuje sposób myślenia i rozumienia oraz wyraża uznanie wobec Prawa Bożego ${ }^{51}$. W walce między prawem umysłu a innym prawem to drugie zawsze odnosi zwycięstwo.

Każde z trzech zdań wersetu 23 kończy się zaimkiem osobowym pierwszej osoby liczby pojedynczej. W ten sposób przywołuje się ludzkie ja i podkreśla jego dramat na podobieństwo kogoś, kto znajduje się w sytuacji nie do roz-

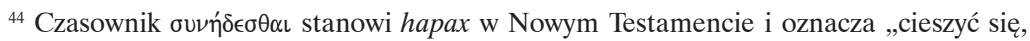
sympatyzować”. W połączeniu z celownikiem przyjmuje znaczenie „radować się”; por. D. J. Moo, The Epistle to the Romans, dz. cyt., s. 461, przyp. 64.

${ }^{45}$ Por. S. Romanello, Una legge buona ma impotente, dz. cyt., 159.

${ }^{46}$ Por. A. Pitta, Lettera ai Romani, dz. cyt., s. 281.

${ }^{47}$ Por. J. E. Toews, Romans, Scottdale, Pensylvania 2004, 376.

${ }^{48}$ Por. S. Romanello, Una legge buona ma impotente, dz. cyt., 160. Prawo Mojżeszowe zostało też wyraźnie odróżnione od samego grzechu, ponieważ jest duchowe (por. w. 14).

${ }^{49}$ Por. A. PitTa, Lettera ai Romani, dz. cyt., s. 281.

${ }^{50}$ Por. R. Penna, Lettera ai Romani, dz. cyt., s. 120.

${ }^{51}$ Por. R. Penna, Lettera ai Romani, dz. cyt., s. 119. Idea ta pojawiła się już w w. 22. 
wiązania i na próżno nad nią debatuje ${ }^{52}$. Dlatego też ja wydobywa z siebie

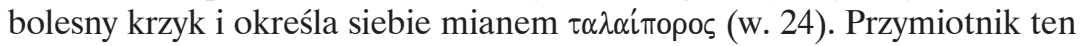
czyni aluzję do nieszczęścia człowieka, który odkrywa własną desperację. W Nowym Testamencie pojawia się jeszcze w Ap 3, 17, gdzie ukazuje kondycję Kościoła w Laodycei. W odróżnieniu jednak od wspomnianej eklezjalnej wspólnoty, która nie wie, że jest nieszczęśliwa, ludzkie ja doskonale uświadamia sobie stan, w którym się znajduje. Dramatyczny krzyk w Rz 7, 24 odnajduje swą bliską paralelę w tragicznej sytuacji Jeftego i jego córki: „Ach, córko moja! Wielki ból mi sprawiasz” (Sdz 11, 35) ${ }^{53}$. Jefte złożył ślub Panu i chcąc być wierny, wiedział, że musi złożyć ofiarę z własnej córki. Te dwa przypadki łączy jedna nie do odwrócenia sytuacja ${ }^{54}$. Desperacja ludzkiego ja wyraża się w niezdolności znalezienia kogoś, kto mógłby je wyrwać,

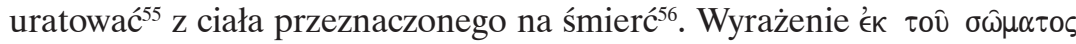

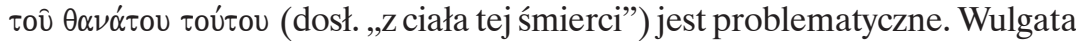
zachowała thumaczenie dosłowne a corpore mortis huius. Pozycja toútou nie

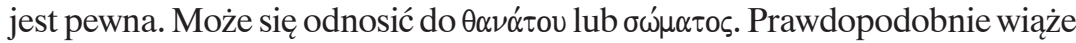
się z $\sigma \omega ́ \mu \alpha \tau o \varsigma$, bo śmierć nie była wcześniej wzmiankowana ${ }^{57}$. Paweł nie myśli o wyzwoleniu ,z tego ciała” w znaczeniu fizycznym. Prośba nie ma wydźwięku dualistycznego czy gnostycznego ${ }^{58}$. W wersetach poprzednich apostoł ukazał całościową koncepcję ludzkiego ja . „To ciało” dotyczy więc całego człowieka, który zmierza ku śmierci, będąc pod władzą grzechu. Wyzwolenie polega zatem na wyrwaniu, uwolnieniu $\mathrm{z}$ tej egzystencjalnej sytuacji59.

W beznadziejną sytuację ludzkiego ja Paweł wprowadza nagle podziękowanie Bogu przez Jezusa Chrystusa (por. w. 25a). Ma ono charakter doksologii i podkreśla pośrednictwo Jezusa Chrystusa w dziele usprawiedliwienia i odrodzenia człowieka. Temat ten jest fundamentalny dla paulini-

52 Por. tamże, s. 117.

${ }^{53}$ Por. A. Pitta, Lettera ai Romani, dz. cyt., s. 282.

${ }^{54}$ Dramatycznemu wołaniu ludzkiego ja odpowiada także ból pewnego rabina: „biada mi z powodu mego złego instynktu, biada mi z powodu mego Stwórcy. Gdy bowiem sprzeciwiam się złemu instynktowi, to mnie dręczy, gdy zaś mu ustępuję - karze mnie Bóg" (H. L. Strack, P. Billerbeck, Kommentar zum Neuen Testament aus Talmud und Midrasch, dz. cyt., t. 3, s. 240).

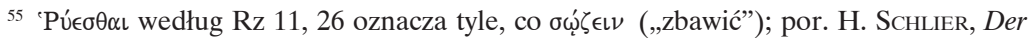
Römerbrief, dz. cyt., s. 235.

${ }^{56}$ Por. A. Pitta, Lettera ai Romani, dz. cyt., s. 282.

${ }^{57}$ Por. H. Schlier, Der Römerbrief, dz. cyt., s. 235. Konstrukcja grecka prawdopodobnie odpowiada też konstrukcji semickiej. Dlatego zaimek łączyłby się z pierwszym rzeczownikiem; por. M. Zerwick, Biblical greek, Roma $1987^{3}$, s. 15, par. 41.

${ }^{58}$ Por. E. Lohse, Der Brief an die Römer, dz. cyt., s. 223.

${ }^{59}$ Por. R. Penna, Lettera ai Romani, dz. cyt., s. 122. 
zmu i szczególnie widoczny w Liście do Rzymian (por. 5, 1. 11. 21.; 7, 4) ${ }^{60}$. Wdzięczność względem Boga i Jego Syna brzmi w 7, 25a jak konkluzja, dlatego też trudno zrozumieć, dlaczego w. 25b znów powraca do tego, co już zostało powiedziane, i ponownie przytacza kontrast między dwoma prawami: Boga i grzechu. Nadto w. 25b przerywa myśl Pawła, która logicznie łączy 7, 25a z 8, $1^{61}$. Jawi się więc jako bezużyteczne, wtrącone zdanie. Poza tym ten rodzaj streszczenia (w. 25b) nie harmonizuje z wcześniejszym języ-

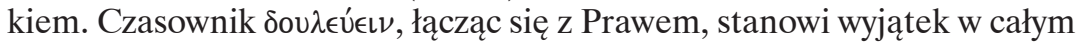
piśmiennictwie Pawłowym. Oprócz tego ja w w. 25b rozdwaja się na umysł i ciało, które służą tutaj antropologicznemu dualizmowi ${ }^{62}$. Przypuszcza się więc, że tego wersetu nie było w Pawłowym oryginale, lecz znalazł się w jakimś rękopisie jako glosa i został wprowadzony do tekstu ${ }^{63}$.

\section{Wnioski}

Rz 7,14- 25 opisuje sytuację egzystencjalną człowieka oddzielonego od Chrystusa. Cierpi on na wewnętrzne rozbicie. Nie rozumie samego siebie. Świetnie wie, co powinien czynić, ma dobre intencje, jednak chcenie i działanie nie mogą się w nim spotkać. Nosi w sobie wewnętrzny dramat. Chciałby być po stronie Boga, ale moc grzechu skutecznie popycha go w kierunku zła. Prawo, chociaż jest duchowe i boskie, nie potrafi go wyleczyć z wewnętrznej bezsilności. Lament frustracji nie jest jednak ostatnim słowem tej perykopy. Mroczne wyznanie ludzkiego ja zamienia się w pieśń

\footnotetext{
${ }^{60}$ Por. tamże.

${ }^{61}$ Por. tamże.

${ }^{62}$ Por. H. Schlier, Der Römerbrief, dz. cyt., s. 235.
}

${ }^{63}$ Por. U. Wilckens, Der Brief an die Römer (Röm 6-11), t. 2, Zürich, Neukirchen-Vluyn $1993^{3}$, s. 87 (Evangelisch-Katholischer Kommentar zum Neuen Testament, 6.2); por. także R. Penna, Lettera ai Romani, dz. cyt., s. 123; H. Schlier, Der Römerbrief, dz. cyt., s. 235. Istnieją też odmienne opinie. A. Pitta sądzi, iż w. 25a tworzy figurę retoryczną hysteron proteron, czyli antycypację względem w. 25b i Rz 8. Uważa, iż umysł i ciało nie sprzeciwiają się jako takie, ponieważ przynależą do tego samego ,ja” - por. Lettera ai Romani, dz. cyt., s. 283-284. Również D. Zeller jest zdania, iż rozum i ciało ukazują się tutaj jako dwie funkcje tego samego ja, które jest rozdarte. Nadto twierdzi, że usunięcie w. 25 b sprawia, że Rz 8, 1 źle łączy się z w. 25 i sam musi być wyjaśniony jako glosa - por. Der Brief an die Römer, dz. cyt., s. 145. S. Légasse też jest przeciwny, by uznać w. 25b jako glosę. Wysuwa przypuszczenie, że w. 25 b był utworzony przez Pawła jako element wskazujący na przejście z 7, 25a do 8, 1 - por. L'épître de Paul aux Romains, dz. cyt., s. 471. Również E. Lohse opowiada się za zachowaniem w. 25b. Dostrzega w nim lectio difficilior. Pisze, iż nie jest rzeczą nadzwyczajną, że w żydowskich i wczesnochrześcijańskich tekstach wprowadza się błogosławieństwo w dotychczasowy tok myśli, aby oddać cześć Bogu. Werset 25b funkcjonuje względem wcześniejszego uwielbienia jako streszczenie opisujące w zwięzłej formie stan nieodkupionego człowieka - por. Der Brief an die Römer, dz. cyt., s. 224. Wobec tych sprzecznych ze sobą stanowisk, wydaje się, że rozstrzygającym jest argument językowy, by przychylić się do opinii uznających w. 25b jako glosę. 
dziękczynną, która wprowadza w wyzwalające, zbawcze dzieło dokonane w Chrystusie (por. Rz 8).

Kraków

STANISEAW WITKOWSKI MS

\section{Summary}

The drama of human ego (Rom 7: 14-25)

Rom 7: 14-25 describes the existential situation of a man separated from Christ. He suffers from internal dissociation. He does not understand himself. He knows perfectly what he should do, he has good intentions, yet his will and actions cannot get together. He carries an internal drama. He would like to be on God's side, but the power of sin effectively pushes him towards evil. Law, though spiritual and divine, is not able to heal him from his internal powerlessness. However, lament of frustration is not the last word of this pericope. The dark confession of human ego changes into a hymn of thanksgiving that leads into the liberating, saving act accomplished in Christ (cf. Rom 8). 